sequel to his observation and did not know of his mention in any publication nor in Ayd and Blackwell's (1970) book, Discoveries in Biological Psychiatry.

I suspect that Professor Blackwell is once again suffering from 'cryptoamnesia', this time in his reference to "manufacturers', myopic files". In the 1970s, such files were part of his responsibility, when working for a "manufacturer", and if 'myopic' who should be blamed? However, such a situation is not true in the 1980s, here in the UK. In 1963, medical advisers in the pharmaceutical industry felt it was their job to push reports of adverse reactions aside ("it would be premature and unscientific to warn patients not to eat cheese": Weber, 1963). Today, all serious side-effects have to be recorded within 48 hours of notification to the company. We no longer shoot the mesenger.

\section{Castle Garden}

Petersfield, Hampshire GU32 3AG

Gerald Samuel

\section{References}

SAMUEL, G. \& BLACKWELL, B. (1968) Monoamine oxidase inhibitors and cheese: A process of discovery. British Journal of Hospital Medicine, 2, 942-943.

AYD, F. J. \& BLACKWELL, B. (eds) (1970) Discoveries in Biological Psychiatry. New York: Lippincott.

WEBER, J. C. P. (1963) Tranylcypromine and cheese. Lancet ii, 587.

\section{On Serious Violence During Sleep-Walking}

SIR: Ian Oswald and John Evans in their article (Journal, 1985, 147, 688-691) added important information to our knowledge about violence during sleep. Other sleep disorders, in addition to somnambulism (Podolsky, 1958) can also generate violent behaviour (Raschka, 1984). The term "sleep-related dangerousness' introduced by Moldofsky appears useful. Such behaviour can include car accidents related to narcolepsy and assaultive behaviour related to sleep drunkeness. The criminological and forensic implications of the latter were discussed by Bonkalo (1974). Sleep disorders generating sleeprelated dangerousness are often influenced by drug intake including alcohol. The resulting behaviour is often preventable.

\section{Clarke Institute of Psychiatry \\ 250 College Street \\ Toronto MST IR8 \\ Canada}

\section{References}

Podotsky, E. (1958) Somnambulistic homicide. Diseases of the Nervous System, 20, 534-536.

RASCHKA. L. B. (1984) Sleep and violence. Canadian Journal of Psychiatry, 29, 132-134.

BONKALO. A. (1974) lmpulsive acts and confusional states during incomplete arousal from sleep: criminological and forensic implications. Psychiatric Quarterly, 48, 400-409.

\title{
INDEX TO VOLUME 148
}

We apologise for the delay in publication of the Index to Volume 148 (January to June 1986) which is now enclosed.

\section{A HUNDRED YEARS AGO}

"It might seem a painful thing to deprive of liberty persons who appear so little ailing, were it not that a repeated experience has shown it to be really a vain folly, if not a positive cruelty, to send them forth into the trials of life, when they are utterly unable to encounter them."

Maudsuey, Henry (1860) Cheadle Royal Annual Report.

Reference

Researched by Henry Rollin, Emeritus Consultant Psychiatrist, Horton Hospital, Surrey 